\title{
How the Budget Process Works in the U.S. House Appropriations Committee and Its Implications for the Korean Government
}

\author{
Jae Young Lim*
}

\begin{abstract}
The recent recession and subsequent rescue efforts along with snowballing annual deficits and national debts in the United States have made it urgent for scholars to examine national budget processes across countries. The House Appropriations Committee is a key cog in the annual appropriations process in the United States and understanding how it behaves offers a clue for what to do with central government deficits. I offer a comprehensive review of scholarly contributions on the behavior of House Appropriation Committee since Fenno's seminal works in 1962 and 1966. Then, I note potential lessons that these studies and U.S experiences can offer for the Korean government.
\end{abstract}

Keywords: House Appropriation Committee, appropriations process, lessons for the Korean government

\section{INTRODUCTION}

Recognized as one of the most prestigious and exclusive committees in the U.S. Congress, the House Appropriations Committee used to be often perceived as a budget guardian in the United States thanks to Fenno's monumental studies on the committee (Fenno, 1962 \&1966). ${ }^{1}$ Fenno conducted extensive interviews with congressmen and

1. The House Appropriations Committee differs from other less powerful committees in terms of member goals, autonomy, and committee assignment. Members come to it for the power and prestige membership on it offers, while members of other committees, such as the Interior and Post Office, have the "primary goal of helping their constituents" (Fenno, 1973, p. 5). The House Appropriations Committee is relatively autonomous compared to others such as Foreign Affairs, which is constrained predominantly by the executive branch (Fenno, 1973). Last, members need to demonstrate strong loyalty to their party and party leaders in order to obtain a seat on the committee (Cox \& McCubbins, 2007).

* Jae Young Lim is a limited-term visiting assistant professor in the Department of Public Administration and Policy at the University of Georgia in Athens. E-mail: jylim@uga.edu. I want to thank three KJPS reviewers for their thoughtful and comprehensive comments.

Manuscript received March 8, 2016; out for review May 15, 2017; review completed July 14, 2017; accepted August 1, 2017.

The Korean Journal of Policy Studies, Vol. 32, No. 2 (2017), pp. 1-21.

(C) 2017 by the GSPA, Seoul National University 
House staff and through them showed that the committee is highly integrated, strongly autonomous, and bipartisan. Fenno deeply influenced how scholars and others have viewed the committee.

While some subsequent studies have confirmed Fenno's notion of the committee as a budget guardian, many more studies have raised doubts about it, arguing that its behavior cannot be explained without taking account of what the House majority party wants the committee to do, how congressmen are constrained by electoral and constituency pressures, and how the committee interacts with structural reforms.

This article examines this rich array of studies in the last four decades and, in doing so, illuminates the importance of the House Appropriations Committee in the national budget process. The article proceeds as follows. First, I trace the history of the committee over four periods between 1865 and the present. Second, I review Fenno's work as well as post-Fenno studies on the committee. Third, I outline lessons of studies of the committee and their implications for the Korean government followed by the conclusion.

\section{BACKGROUND: HISTORY OF THE HOUSE APPROPIATIONS COMMITEE}

The budget process, of course, is not determined solely by the House and Senate appropriations committees. It involves months-long negotiations between the Office of Management and Budget and other federal agencies. There is a prolonged annual fight in February after the president submits his budget to Congress that has become a source of frustration to both scholars and lay people alike in recent decades. Rarely have annual appropriations decisions been completed prior to October 1, the start of the federal fiscal year.

Although budget committees - created by the Congressional Budget and Impoundment Control Act of 1974 - attract much attention from the public as the focal point of the congressional budgeting, they have no binding authority over the federal budget. Appropriations committees still determine the expenditure side of the budgetary coin. While appropriations committees in both House and Senate contribute equally when it comes to final appropriations decisions, the House Appropriations Committee has attracted more scholarly attention because it has the constitutional power to initiate appropriations bills. The Senate Appropriations Committee merely reviews decisions by the House committee and typically just increases the appropriation. 


\section{Earlier Years of the House Appropriations Committee, 1865-85}

Before 1865, the Ways and Means Committee in the House possessed the monopoly over both appropriations and revenue decisions. The House Appropriations Committee was created in the aftermath of the Civil War. The war that almost tore apart the young republic put an immense burden on the federal government. But the House Ways and Means Committee was soon overwhelmed by the military spending required to fight the war and then the costs of protecting newly emancipated blacks and assigning federal troops to the defeated South that Reconstruction brought. In 1865, Congress thus decided to make appropriations the jurisdiction of the House Appropriations Committee instead (McCaffery, 1987; Brady, 1987; Wildavsky \& Caiden, 2004).

The committee quickly gained a reputation as the guardian of the federal treasury and secured greater power when the Holman rule was adopted in 1876. The rule gave the committee the power not only to slash expenditures in appropriations bills but also to add amendments to bills (Brady, 1987).

\section{Divesture of the House Appropriations Committee, 1885-1921}

For a while, the committee fulfilled its obligations as the budget cutter. Congress made a practical choice in designating it the sole arbiter of government coffers; the hope was that it would restrain freewheeling spending habits of congressional committees. For much of American history, patronage politics, whereby government positions were routinely purchased with money and party bosses bribed voters, was the norm; members of Congress and state legislatures also heavily engaged in pork barrel spending through which government money was doled out to projects in localities where they resided (Skowronek, 1982; Skocpol, 1995). The committee's role was therefore to protect the country's treasury amid intense pressures from other committees to spend. This mechanism worked for the two decades after the Civil War, but Congress quickly found that the committee robbed members of Congress the money they needed to underwrite patronage politics, the lifeblood for political parties in the nineteenth century. The committee zealously cut the spending of other congressional Committees, so Congress finally decided cut the committee's jurisdiction over many areas in order to restore patronage politics (Brady, 1987; Wildavsky \& Caiden, 2004).

The divesture of the committee was officially announced in 1885 , but it had begun to lose its sole power over appropriations before that. In 1877, the House allowed a rivers and harbors appropriations bill to bypass the committee, and in 1887 , the Agriculture Committee was given the right to appropriate money as well. After 
the committee's official divesture in 1885, the House divided control of the areas it had had jurisdiction over among eight committees (Burkhead, 1967).

The decentralization was closely related to the unprecedented budget surplus of the 1870s. Debates over what to do with the surplus soon erupted. The Republican Party, which represented manufacturing interests, opposed anything that might have reduced tariff revenue or exposed the fragile manufacturing sector to competition with its robust European counterparts. The Democratic Party, on the other hand, wanted to reduce tariffs and allow cheaper goods from abroad to be imported into the country. Congressmen from the South and Midwest also clamored for internal improvement projects. Clashes among congressmen over how to spend the surplus put immense pressure on the committee and contributed to its divesture (Kiewiet \& McCubbins, 1991; Stewart, 1989).

\section{Executive Budgeting and Rise of the Presidency, 1921-74}

By the late 1890s and the early 1900s, increasing deficits began wreaking havoc on federal coffers. ${ }^{2}$ The period saw the two large wars, the Spanish-American War and World War I. In addition, the fragmentation of the appropriations process in Congress encouraged federal agencies to behave as claimants and exploit Congress using coercive tactics. At the same time that fiscal management was mired in waste and pork barrel politics at the federal level, scandal and corruption were rampant across the United States at the municipal level. Progressives' efforts - notably those of William Allen, Henry Bruère, and Frederick Cleveland in the New York Bureau of Municipal Research - to reform their cities helped popularize executive budgeting at the municipal level (Kahn, 1997). Cleveland, in particular, played a pivotal role in leading the Taft Commission on Economy and Efficiency, which gave rise to the Bureau of the Budget and modern executive budgeting in 1921. ${ }^{3}$ The enactment of the Budget and Accounting Act of 1921 shifted the power of national budgeting from Congress to the president. ${ }^{4}$ Fearing that the act would give the president too much power, members of

2. The country ran deficits for 11 of the 17 years between 1894 and 1911 (McCaffery, 1987).

3. The bureau name was later changed to the Office of Management and Budget during the Nixon administration. The name is a misnomer, however, because the office focuses much more on budget than on management.

4. Reforms that seek to increase executive power often face stiff resistance from Congress. But reformers pushing for executive budgeting tried to allay the fears of Congress by arguing that the increased presidential power through executive budgeting was necessary because the government had become too complex to be exclusively overseen by Congress (Kahn, 1997). 
Congress recentralized the appropriations in the House Appropriations Committee.

\section{Congressional Reforms in the 1970s and Their Impact on the House Appropriations Committee}

Many factors contributed to a flurry of congressional reforms in the 1970s. Repeated confrontations between President Nixon and the Democratic Party made the federal budget process tumultuous. On many occasions, Nixon refused to implement the budget approved by Congress and, thus, infuriated congressional Democrats (Schick, 1980 \& 1981). At the same time, budget deficits began to snowball in the late 1960s, owing to the Vietnam War and increasing number of entitlement programs (such as Medicare and Medicaid). Congress formed the Joint Study Committee on Budget Control in 1972, which was tasked with coming up with an alternative to the existing budget process. A series of hearings by the joint committee ushered in passage of the Congressional Budget and Impoundment Control Act of 1974, which Deering and Smith (1997) call "the most important change in the political agenda" in recent decades (193).

The 1974 budget act created two budget committees and the Congressional Budget Office. The budget committees were not to interfere with jurisdictions of appropriations committees in either the House or Senate but to coordinate authorizations, appropriations, and revenue committees. Each year, the budget committees would set revenue and spending targets in broad categories as well as predict whether there would be a federal surplus or deficit. The 1974 budget act also required that Congress adopt two budget resolutions: the first called for the budget committees to supply guidelines to the appropriations committees; the second called for differences among committees regarding the federal budget to be reconciled. The politically neural Congressional Budget Office would arm Congress with broad budget outlooks and economic forecasts (Schick, 1980; Leloup, 1980; Ippolito, 1981; Deering \& Smith, 1997).

Congress itself underwent sweeping reforms in the 1970s. Liberal Democrats, who were tired of conservative Democratic coalitions with Republicans, urged the Democratic Party to introduce changes in the way Congress conducted business that were intended to produce a more coherent party platform that reflected the views of its majority members. ${ }^{5}$ Closed committee meetings became open to the public, and subcommittees secured more power. Adopted in 1973, the Subcommittee Bill of

5. Although Republicans followed the Democratic Party in reform efforts, the Democratic Party, which was the majority party in Congress for most of the last century, was the leader in these efforts. 
Rights introduced rules and procedures designed to enhance the power of subcommittees at the expense of committee chairmen. Members now were able to bid for subcommittee seats. Subcommittees were also given fixed jurisdictions so that they would no longer be subjected to whims of committee chairs. In addition, committee chairs would now be elected via secret vote by the party caucus, and the caucus rather than the committee chairmen would also elect the subcommittee chairs, giving party leaders more power than they had ever had (Rohde, 1991; Deering \& Smith, 1997). The caucus also introduced more open rules for floor deliberations so that subcommittee decisions that conflicted with the plurality of the majority party could be defeated or amended. Party leaders also could refer a bill to more than one committee (Rohde, 1991; Deering \& Smith, 1997).

The two budget committees began to interfere with the workings of the House and Senate appropriations committees (Schick, 1980; Wildavsky \& Caiden, 2004; Schick, 2007). Some have criticized the 1974 budget act, arguing that it has institutionalized budget conflict (Wildavsky \& Caiden, 2004; Schick, 2007). So if the two budget committees were dissolved, it is not clear who would monitor the national budget. Another problem is that entitlement (mandatory) spending - such as Social Security, Medicare, Medicaid, farm subsidies, food stamps, student loan guarantees, and so on-which constitutes over $60 \%$ of the national budget, does not go through the annual appropriations process. Tinkering with the budget process would not solve the problem of ever-shrinking discretional spending - appropriations funds that go through Congress (Schick, 2007).

\section{SCHOLARLY RESEARCH ON THE HOUSE APPROPRIATIONS COMMITTEE}

\section{Fenno and the House Appropriations Committee as a Budget Guardian}

Fenno $(1962,1966, \& 1973)$ made the first systemic attempt to examine behavior of the House Appropriations Committee. Fenno conducted 179 interviews with congressional members and staff over three years and concluded that it was a highly integrated committee. Fenno borrowed heavily from sociology and focused on the internal traits of the committee, examining the committee in light of concepts such as socialization, specialization, stability, integration, unity, attractiveness, internal control, and autonomy (1962 \& 1966). ${ }^{6}$ The committee was defined by a cult of hard

6. Fenno mentions "social systems theory" numerous times in his article and book (1962 \& 
work, and its members prided themselves on it. Devotion to that cult, in turn, reinforced its reputation as the hardest working committee on Capitol Hill.

Junior members had to go through a period of apprenticeship, during which they were supposed to defer to senior members. After their apprenticeship, they were free to voice their opinions. Members rarely left the committee voluntarily. Fenno studied the committee between 1947 and 1961 and observed that 15 of the 42 members on the committee in 1947 were still on it in 1961.

One of Fenno's most important observations, though, was that committee members exhibited little partisanship in following the "norm of economy" and lopping off budget proposals full of fat (1962, p. 312). Members of the committee were deliberately assigned to a subcommittee that had nothing to do with their constituency interests. For instance, the Interior Subcommittee was filled with nonwesterners (Fenno, 1966).

A number of studies of the committee followed on the heels of Fenno's work. Some scholars confirmed Fenno's notion of the committee as a budget guardian while others questioned whether it alone was capable of making appropriations decisions and outlined the many political and economic constraints on it.

\section{Post-Fenno Studies}

\section{The House Appropriations Committee as a Budget Guardian}

Some scholars confirmed the Fenno's notion of the committee as a budget guardian. Savage (1991) examined whether its members shunned "the norm of universalism" and distributive politics and whether they were so-called saints who put their reelection or their colleagues' election at risk by their devotion to budget cuts (pp. $329,343) .{ }^{7}$ For this purpose, Savage looked at how members handled academic pork. Focusing on two appropriations subcommittees, the Labor, Health and Human Services, Education, and Related Agencies subcommittee and the Veterans Administration, Housing and Urban Development, and Independent Agencies subcommittee where nondefense research programs are heavily appropriated, Savage (1991) found that some committee members resisted bills containing heavy pork by offering amendments (or points of order) on the floor. In this way, more than $\$ 100$ million

1966), among whose leading figures are George Homans, Robert K. Merton, Talcott Parsons, and Edward Shils.

7. According to Shepsle and Weingast (1981), the "norm of universalism" assumes that congresspeople are risk averse and that they support bills containing distributive projects in order to avoid the "wrath of ever-shifting minimum-winning coalitions" in the House (Savage 1991, p. 343). 
was stripped from academic pork in FY 1989 and FY 1990. Savage showed that the reputation and influence of these members as senior committee members protected them from reprisals from colleagues and constituents.

Geiger (1994) examined budget data for the same 36 federal agencies that Fenno investigated for his study (1966), but for a different period (between FY 1963 and FY 1982). At the aggregate level, she found that the House Appropriations Committee became less stringent in slashing the budget in the decades following Fenno's study (1966) but still acted as a budget guardian most of the time (57.8\%). Geiger also showed that at the microlevel the Agriculture Subcommittee and the Labor, Health, Education, and Welfare Subcommittee continued to be budget claimants. These two committees alone accounted for $49 \%$ of budget increases compared to the president's requests. By showing how the committee cut the president's budget requests a majority of the time, Geiger confirms Fenno's description of it as a budget guardian.

Fenno's observation that the committee operated as a budget guardian also received support from Maass (1983), who examined number of amendments proposed to appropriations bills and found that those aiming to increase the amount of appropriations were frequently defeated. Likewise, Maass found that unity and nonpartisanship still prevailed in the committee and concluded that the 1974 budget act and the creation of the two budget committees didn't transform the committee from a guardian of federal coffers into a claimant.

The findings of Gist's (1978) study of Senate appropriations subcommittees are applicable to the House Appropriations Committee. Spending spiraled out of control in the decade before his study, Gist argued, a consequences of growing subcommittee prestige and specialization. ${ }^{8}$ According to him, subcommittees that were able to exercise more control over their jurisdictions (such as Defense and Public Works) were more prestigious, had more senior members than junior members, and experienced less turnover. These findings showed implicitly that Senate appropriations committee members - often perceived to be the opposite of their penny-pinching House counterparts - also sought to control the purse as a way to maximize their influence on appropriations decisions.

The problems with these studies, though, are that they did not discuss exogenous variables that may have influenced behavior of the committee. Major changes occurred in Congress after Fenno published his seminal studies, but Savage (1991)

8. Entitlement programs (such as social security, Medicare, Medicaid, and interest payment) are the source of out-of-control spending. These programs are not subject to the annual appropriations process, but they makes up more than $60 \%$ of the annual budget. Discretionary spending - subject to annual appropriations process - has shrunk to less than $40 \%$ of the federal budget (Lee et al., 2013). 
and Geiger (1978) in particular only looked at final appropriations decisions and changes in apportionment of appropriations (compared to the year before) made by the appropriations subcommittees without examining internal (such as the increased partisanship in recent decades) or external changes (economic growth and performance). ${ }^{9}$

\section{Distributive Politics, Electoral Connection Theory, and the House Appropriations Committee as a Claimant}

Other scholars questioned Fenno's description of he House Appropriations Committee as a highly autonomous body that worked hard to manage the spending profligacy of Congress. One school of such scholars examined Congress through the lens of distributive politics (Shepsle, 1978; Shepsle \& Weingast, 1984; Ferejohn, 1974). Distributive politics theory, taking cues from Mayhew's electoral connection theory, recognizes that economic benefits are concentrated while costs tend to be diffused and that the federal government faces less pressure to reduce appropriations than state governments (Weingast, Shepsle, \& Johnson, 1981). ${ }^{10}$

An electoral connection model of the appropriations process in Congress was tested by Kiewiet and McCubbins (1985). The study explored whether appropriations decisions are tied to members' reelection hopes. Examining 37 federal agencies from FY 1948 to FY 1979, the study found that Congress tended to be less economical in making appropriations during election years compared to nonelection years. Economic performance also influenced appropriations decisions. High unemployment leads to increased levels of appropriations, especially for agencies related to public works because members are able to claim credit for dollars and jobs created for their districts. High inflation, conversely, leads members to reduce appropriations. These findings directly countered Fenno's notion of the committee as a guardian of the federal treasury.

Adler (2000) examined the relation between House appropriations subcommittees

9. For instance, Geiger did not address how much agencies increased their budget compared to the year before as a result of the president's budget requests. If an agency increased its budget significantly compared to the year before, a slight budget cut by the House Appropriations Committee undercuts the idea that it acts as a budget guardian.

10. Scholars in public budgeting and finance note that most states except Vermont are required to balance their budget although there are variations in balanced budget rules. In addition, many states have expenditure and revenue limitations that constrain their budgets. The federal government, on the other hand, has fewer constraints if any on borrowing and spending (Briffault, 1996). 
and their constituency characteristics. Using a Monte Carlo simulation technique and drawing on a rich dataset describing the characteristics of all 435 congressional districts for the period between 1959 and 1998, the study tackled the question whether the House Appropriations Committee is a budget guardian or claimant and found that several House appropriations subcommittees - such as Agriculture and Energy and Water - were populated by members with a "disproportionate need" for the programs within their jurisdictions (Adler 2000, 112). These findings certainly undermine Fenno's notion of the committee as a budget guardian.

\section{Majority Party Constraint on the House Appropriations Committee}

If the distributive politics theory disputed Fenno's findings on the House Appropriations Committee by focusing on the relation between members of Congress and their electoral chances, the conditional party government theory suggested that the committee is not an autonomous body but rather is constrained by the majority party.

Aldrich and Rohde (2000) applied this theory to the committee under the Republican-controlled House. ${ }^{11}$ The homogeneity of preferences among the Republican contingent in the 104th House (1995-96), they argued, enhanced the influence of Republican leaders, which in turn helped advance the policy goals of the Republican Party. The election of 1994 produced the first Republican majority in four decades. The GOP leadership, represented by Newt Gingrich, seized this opportunity to change the way the House Appropriations Committee operated and to slash programs that it didn't trust. Gingrich bypassed several ranking members and chose Robert Livingston of Louisiana, the fifth-ranking member, as the new chair of the committee. In addition, the speaker assigned to it seven newly elected members of Congress who were loyal to him. The GOP leadership also asked the committee to take over a legislative responsibility that normally belongs to authorization committees, which make laws and issue spending requests to the House Appropriations Committee (Oleszek, 2011). The leadership also warned the committee that "any authorizing language in an appropriation bill would be subject to a point of order if it doesn't reflect a leadership position" (Dick Armey quoted in Aldrich and Rohde, 2000, p. 15). Consequently, number of partisan roll-call votes on amendments in the 104th Congress jumped to 133 , a dramatic increase from 14 in the $103 \mathrm{rd}$. The findings of the study clearly

11. Popularized by Rohde (1991), the conditional party government theory implies that the majority party will be successful in shifting policies from the median position of members' preferences in Congress toward the median position of the majority party (Aldrich and Rohde, 2000, p. 2). 
showed that the committee is not an autonomous, bipartisan body; rather, the majority party leadership can and does exert significant influence on it.

The theory the committee is constrained by the majority party received added support from Kiewiet and McCubbins (1991). The study claimed that appropriations decisions depend on which majority party controls Congress. Based on budget data for the period between FY 1948 and FY 1985, the study found that when the Democrats had a majority of the seats in both houses, appropriations awarded to agencies jumped up significantly. The study also revisited the claim that the 1885 divesture of the committee was responsible for overspending after 1885. According to the study, it was not the divesture but the Republican Party solution to mounting surpluses of the 1870 s and 1880 s that ultimately explains the subsequent lenient spending. Likewise, it was not the 1974 budget act that caused budget deficits. Rather, they were the Democratic Party solution (focusing on spending on domestic programs) to the Republican president's budget requests. McCubbins (1990) flatly refuted the idea that the House Appropriations Committee is the treasury guardian; "There is no evidence that it was a guardian or that its function has in fact changed. It has been, and still is a check upon the authority of the other standing committees in the House, a check used by the majority-party leadership to ensure that the policies pursued by the other standing committees in the House reflect the collective goals of the membership of the majority party (p.149)." 12 No procedures and institutional arrangements that have been put in place have prevented congressional parties from "pressing on with their policy priorities" (Kiewiet \& McCubbins, 1991, p.94).

\section{The Institutional Structures of the House Appropriations Committee}

Rather than looking at the committee as either the treasury guardian or claimant, some scholars have explored the dynamics between institutional structures and appropriations. Brady and Morgan (1987) examined how decentralization and recentralization of the committee affected money decisions between 1865 and 1948. What they found is that the divesture led to increased spending for the period between 1887 and 1915. Easy accessibility to a seat on the committee (indicating that it had a high turnover rate) clearly led to overspending. For instance, the committee focused on

12. McCubbins also argued that the 1974 budget act ensures the stamp of the majority party leadership on the Budget Committee. Members of the Budget Committee are "handpicked" by the leadership, which is not the case with other committees. Moreover, tenure and seniority are moot. Controlling the Budget Committee, thus, allows the majority party to use the newly created budget process to ensure that decisions made in Congress take the priorities of the majority party into account. 
tightening the federal budget during the $1867-79$ period when less than $5 \%$ of the House members had a seat on the it, but during the 49th Congress, after the divesture, over $45 \%$ of the House membership had a seat on it. The reform contributed to increased spending in subsequent years until the committee was recentralized in 1921.

Some researchers have also found that the dynamics between realignments and appropriations also shapes how the committee behaves. Brady (1988) found that during the New Deal period between 1933 and 1939, appropriations increased on average by $34.1 \%$. Political realignment, he concluded, ushers in a high turnover of committee members and escalates partisanship. High committee turnover ratesspurred by electoral results during a critical realignment period-produce "the most dramatic changes in partisanship and in expenditures" (Brady, 1988, p.124).

Structural change can affect appropriations decisions in the House (Stewart, 1988). Stewart (1988) examined roughly the same period (1871-22) as Brady did. Using data culled from 11 annual appropriations bills and differentiating appropriations by legislative committees (which were given appropriations jurisdictions after 1885) from those by the House Appropriations Committee, the study found that while legislative committees became more generous with respect to spending, as expected, after 1885, the House Appropriations Committee too became more generous after 1885 , (although that is partially the effect of the divesture of the committee on spending decisions).

By emphasizing the dynamics between structures and budgetary outcomes and political and economic contexts, studies exploring the institutional structures of the committee also contribute to understanding it in particular and the appropriations process in general.

\section{IMPLICATIONS OF THE HISTORY OF THE HOUSE APPROPRIATIONS COMMITTEE AND STUDIES OF IT FOR KOREA}

\section{Korea's Budget Process}

Korea's budget process is governed by the Constitution and a series of laws: the National Finance Act, the Local Finance Act, the National Assembly Act, the Act on Management of Subsidies, the Tax Act, the Framework Act on Management of Charges, the Act on Public-Private Partnership in Infrastructures, and others (Ministry of Strategy and Finance, 2014). Chapter 54 of the Constitution grants the execu- 
tive branch the authority to draft the national budget and the National Assembly the power to approve it.

Thus, as in most other countries, Korea's budget process gets under way in executive office. Once prepared, the president's budget is submitted to the National Assembly, where it undergoes a preliminary review by standing committees and then a comprehensive review by the Special Committee on Budget and Accounts. In a sense, this committee is the Korean counterpart of the U.S. House Appropriations Committee. But unlike its U.S. counterpart, it is not a standing committee; rather, it is a special committee that regularly convenes to discuss budget matters. Importantly, it is a not year-round committee like the House Appropriations Committee.

The committee has 90 days (September 1 to November 30) to evaluate the president's budget along with revisions suggested by other standing committees. It has only 30 days for its own review, though, so that it is forced to cover budget matters in a rushed fashion and focuses mainly on politically controversial items. The short amount of time it has to review the budget makes it difficult for it to make rational decisions on complicated items. To make matters worse, if the committee fails to enact the budget, the president's version is automatically adopted and signed by the president, making mockery of the legislature's role in checking executive power in a democracy. According to Lee and Lee (2017), the government party in the legislature uncritically follows the president's positions on the budget matters and, due to time constraints, the process of finalizing a budget is filled with behind-the-scene negotiations and pork barrel spending. Many functions of the Special Committee on Budgets and Accounts overlap with those of standing committees: executive officials serve both in it and in the standing committee of their jurisdiction, budget items are coordinated by both, and both review briefings by budget experts. There are no clear, differentiated duties between it and standing committees; the budget review process is decentralized and bottom up rather than centralized and top down. Since the Special Committee on Budgets and Accounts is not a standing committee, its members and its chair change every year. Equal opportunity and political considerations for members of the National Assembly guide member selection: 50 out of the total 300 members of the National Assembly (17\%) are members of it. The rotating membership makes it difficult for the committee's members to build the institutional knowledge and mutual collegiality needed for effective budgeting (Lee \& Lee, 2017). Moreover, under chapter 57 of the Constitution, the National Assembly cannot increase the proposed budget by the executive branch or create new budgetary items without the latter's agreement. This greatly constrains and weakens the National Assembly's power to deliberate on budgetary matters (Ministry of Strategy and Finance, 2014). 


\section{Lessons for the Korean Government}

These U.S. experiences and the studies of the House Appropriations Committee offer valuable lessons for the Korean central government. First, decentralizing the appropriations process is harmful. The Ways and Means Committee in the United States between 1802 in the early days of the American republic and 1865 in the aftermath of the Civil War was responsible for both appropriations and taxation. The system worked for a while because the federal government was small and intended to be small by the framers of the Constitution and the dominant political faction, the Jeffersonian Democratic Republicans, who believed that the role of the federal government should be minimized so as to protect the rights of states and individuals (Wood, 1969). The revenue system of the federal government was simple; tariffs and excise taxes were levied only on such items as alcohol and served as permanent revenue sources. The Civil War, however, exposed the complexities of governance for the first time. Immense spending resulting from conducting the war and the reconstruction and monitoring of the South after the war posed insurmountable challenges to the Ways and Means Committee (Brady, 1987). The solution was to centralize the nation's appropriations process, but centralization went too far, and after the House Appropriations Committee began to encroach on other committees' jurisdictions, it lost more than half of its appropriations jurisdictions (Brady, 1987).

Assigning responsibility of appropriations solely to an appropriations committee can help centralize the budgetary process. Authorization committees have no reason to restrain themselves when it comes to spending. ${ }^{13}$ Spending equates to power in the legislature, enabling members of the legislature to fund their own projects and, in turn, take credit for these projects, which is essential for any politician who wants to get reelected (Mayhew, 1974). As a result, a fragmented legislative appropriations process offers a fertile ground for overspending. The centralization of appropriations process in appropriations committees counters this impulse and helps preserve the integrity of the legislature as the nation's budget guardian.

13. In the U.S. Congress, authorizing committees are separate from appropriations committees, and their task is to authorize legislation that creates the "legal basis" for federal agencies and programs (Schick, 2007, p. 191). Implementing the latter, however, requires actual appropriations by the appropriations committees Naturally, as I have noted, tension between authorizing and appropriations committees have remained high since the House Appropriations Committee was created in the 1860s. Authorizing committees routinely attempt to bypass appropriations committees to secure spending by creating so-called entitlement programs, permanent programs that do not require annual appropriations, such as the food stamp program, Medicaid, Medicare, and Social Security. 
Appropriations committees can also serve as a check on the president's budget power. The democratic process is undermined and checks and balances between the executive and legislative branches can suffer if the legislature loses the ability to monitor the executive budget. The congressional appropriations process in the United States has evolved into a check against potential executive abuse. ${ }^{14}$ The Civil War greatly increased the power of the executive branch, as President Lincoln could secure lump sum appropriations as well as operate on the assumption of a coercive deficiency by spending first and letting Congress appropriate funds later. Congress created the House Appropriations Committee in 1865 to counter a too powerful presidency. After the committee lost its power by encroaching on the jurisdictional territory of other committees, the congressional budget process underwent a fragmentation that continued in the early twentieth century. The president gained the power to revise the national budget for the first time in the nation's history through the Budget and Accounting Act of 1921, but Congress restored the jurisdictional power of the appropriations committee to check a potential abuse of executive power.

It is important for the National Assembly in Korea to make its appropriations committee as a permanent, standing committee, which will allow it to foster the institutional expertise needed to improve the appropriations process. Building expertise takes years of digesting details. A standing committee also forces its members to consider those across the aisle. Standing committees helps ease partisanship, allowing members from different parties to work together in the name of common goals such as economy and efficiency and fostering mutual respect and friendship that enables members to learn from each other.

Members of the appropriations committee should come from safe districts (dis-

14. The National Assembly enjoys far less power than the U.S. Congress does. The U.S. Congress is considered a keystone institution that puts breaks on the executive branch (Fiorina, 1977). It monopolized the federal budget process for a long time, from the country's founding to the early 20th century; after a period of yielding power to the president, it regained its power against the executive branch thanks to 1974 budget act. In Korea, the recent impeachment of President Park Geun-hye clearly shows how much the executive branch can abuse its power when the legislature is weak. Members of the National Assembly tend to uncritically follow the president's lead on policy matters if both are from the same party (Lee \& Lee, 2017). A legislature that is not independent from the executive branch can harm the democratic process in which checks and balances help prevent executive abuse. Recently, however, the power and independence of the National Assembly has been growing. Before 2004, the National Assembly did not even have an organization to assist its budgetary policy making. The establishment of the National Assembly Budget Office has provided an arsenal to the National Assembly that it can draw on to check and counter the president's budget proposals. 
tricts in which voters favor one party over the other by a wide margin) so that reelection pressure and the consequent urge to spend more rather than spend less are greatly reduced. ${ }^{15}$ Another way to diffuse reelection pressure is to begin the annual appropriations process after elections. Making it more difficult to engage in pork barrel spending in election seasons can contribute to a fiscally responsible budget process, permitting the appropriations committee to act as a guardian of a nation's treasury instead of as a freewheeling spender.

Entitlement spending presents a severe threat to the legislative budget process as well as the appropriations committee. When a nation's spending is under control, the appropriation committee can be an effective guardian of the national budget. However, when a country's appropriates too much for entitlement programs that are effective permanent and do not undergo the annual appropriations process unless they are to be altered by the legislature, there is not much left in government coffers for the appropriations committee to control. In fact, the two appropriations committees in the United States have lost considerable power over the years. In the 1950s, the two committees controlled over $50 \%$ of the U.S. federal budget in the annual appropriations process; as of fiscal year 2015, the two are responsible only for approximately $35 \%$ of the central budget (Wildavsky \& Caiden, 2004; Schick, 2007). This offers a valuable lesson for the Korean government. As the latter turns into a mature welfare state, the country may be tempted to make certain welfare programs permanent mandatory, entitlement programs. ${ }^{16}$ Once this is done, it is not easy to reverse course, as benefi-

15. Roughly 4 out of 10 members of the National Assembly were newly elected in the 2016 election for the 20th National Assembly (2016-20) (Kim, 2016). Conversely, the makeup of the 115th Congress (2017-19) indicates that the average tenure of the members of the U.S. Congress was 9.4 years (more than four terms) for representatives and 10.1 years (close to two terms, with each term lasting 6 years) for senators. Only $11 \%$ were first-term representatives, and only 7\% of senators had no prior service in the upper chamber (Glassman and Wilhelm, 2017). Putting numbers in perspective, it is clear that members of the U.S. Congress tend to enjoy long tenures and that there is little room for newcomers. This may indicate that members of the U.S. Congress hail from safer districts than their Korean counterparts. However, a direct comparison between the two legislative institutions is guesswork at best. They are constrained by different electoral rules and mechanisms. For instance, any politician in the United States can declare a candidacy for a party primary, while Korean politicians must either wait for a nod from party bosses or run as an independent. Only 11 out of 300 elected members for the 115th National Assembly were independents and 5 of those have by this time moved back to the party to which they had previously belonged.

16. There is a growing concern that Korea may follow the United States in its budget politics. The percentage of discretionary spending in Korea was 50.9\% (\$204 trillion out of 
ciaries from those programs will put immense pressure on political leaders to keep these programs in place. Consequently, mandatory spending can eat up a significant portion of the country's central budget, and even with the existence of a standing committee like the appropriations committee, the country may find it extraordinarily difficult to resist the pressure to overspend. Unless the Korean government plans to significantly raise taxes or the marginal tax rate for the haves, it may find itself facing the same budget challenges that the federal government in the United States has faced year in and year out in recent decades. ${ }^{17}$

$\$ 400.5$ trillion) in FY 2017. While the amount of discretionary spending has increased by $1.8 \%$ over the last five years, its percentage has fallen from 54\% in FY 2013 to 50.9\% in FY 2017 (National Assembly Budget Office, 2017). Conversely, discretionary spending has continued to decrease in the United States; its share of the federal budget plummeted from over 50\% in 1974 to $33 \%$ in 2014 with entitlement spending - represented by likes of Medicaid, Medicare, food stamp, and agricultural subsidies - showing no signs of abatement (Office of Management and Budget, 2016). In fact, the Congressional Budget Office predicts that Social Security trust fund will run out of money in the mid-2030s if no reform is undertaken; the Medicare trust fund faces the same fate (Lee \& Joyce, 2013). While the level of Korea's welfare spending is nowhere near that of America, the continuous upward trend of welfare spending and the nation's evolution as a welfare state will eventually force it to grapple with how to allocate the national budget effectively in the face of an ever-shrinking amount of discretionary spending.

17. Distributive politics, partisanship, and institutional perspectives are important in understanding legislative politics. Distributive spending has attracted scholarly attention in recent decades (Shepsle, 1978; Shepsle \& Weingast, 1984; Ferejohn, 1974). And the media occasionally produce articles that lead to public outrage. The recent "Bridge to Nowhere" incident brought national embarrassment to members of Congress and, particularly, Senator Ted Stevens and Representative Don Young of Alaska. The bridge, appropriated for over $\$ 300$ million, was scheduled to connect the Gravina Island Bridge to a tiny island with 50 residents (Lende, 2005); the project was later canceled by Congress in the face of fierce criticisms from the public as well as the media. Still, distributive spending is not as serious a problem as it has been portrayed to be in the media. In recent years, pork barrel spending has accounted for less than $1 \%$ of the federal budget (Rubin, 2017); moreover, it shrunk dramatically during the Obama administration, accounting for $\$ 4.2$ billion out of the total federal budget of $\$ 3.7$ trillion (0.001\%) (Citizens Against Government Waste, 2015).

A more important question is how partisanship influences institutional dynamics in appropriations politics. Institutional norms represented by the idea of appropriations committees as "budget guardians" have been replaced by bitter partisan battles between the Republican Party and Democratic Party. In recent years, as the portion of discretionary spending has decreased - spending that is subject to the annual appropriations process - the two parties have waged budgetary tugs of war, with the Republic Party focusing on increasing military 
Ensuring that will of the majority party does not negatively influence appropriations process is critical. Although Kiewiet and McCubbins (1991) argued that nothing can prevent the majority from pushing for its priorities in the appropriations process, having the appropriations committee as a standing committee and giving its members the time to cultivate friendship, expertise, and a shared vision economy and balance can help alleviate potential concerns about the way the vagaries of politics may affect the appropriations process.

\section{CONCLUSION}

Studies on public budgeting in general and the federal budgetary process in particular ebb and flow. Studies of the House Appropriations Committee flourished between the 1970s and the early 1990s, when economy stagnated and deficits mounted. There were far fewer of them in the mid- to late 1990s, when economy was robust. The recent recession - which some argue was one of the worst since the Great Depression - has led to snowballing deficits owing to slow economic recovery and money spent on the stimulus packages and bank bailouts (Lee et al., 2013). The impending retirement of the baby boom generation in throngs and ever-increasing uncontrollable spending may paralyze the federal budget in coming years.

Tumultuous times like this call on scholars to fully examine how the budget process works across countries. Studies of appropriations committees and particularly the House Appropriations Committee in the United States are rich in details and broad in scope. Examining them offer valuable lessons for the Korean government, which does not have a permanent standing committee responsible for implementing the annual appropriations process.

spending by cutting nondefense spending and the Democratic Party seeking to preserve social and welfare programs by cutting military spending. Lost in these battles were the institutional norms that made the House Appropriations Committee a committee built on collegiality and competence as a "budget guardian." 


\section{REFERENCES}

Adler, E. S. 2000. Constituency characteristics and the "guardian" model of appropriations subcommittees, 1959-1998. American Journal of Political Science, 44(1): 104-114.

Aldrich, J. H., \&, David, W. 2000. The Republican revolution and the House Appropriations Committee. Journal of Politics, 62(1): 1-33.

Brady, D., \& Morgan, M. A. 1987. Reforming the structure of the House appropriations process: The effects of the 1885 and 1919-1920 reforms on money decisions. In M. D. McCubbins \& T. Sullivan (eds.), Congress: Structure and policy (pp. 207-234). New York: Cambridge University Press.

Brady, D. W. 1988. Critical elections and congressional policy making. Stanford, CA: Stanford University Press.

Briffault, R. 1996. Balancing acts: The reality behind balanced budget requirements. New York: Twentieth-Century Fund Press.

Burkhead, J. 1967. Government budgeting. New York: John Wiley.

Cox, G. W., \& McCubbins, M. D. 2007. Legislative leviathan: Party government in the House. New York: Cambridge University Press.

Deering, C. J., \& Smith, S. S. 1997. Committees in Congress. Washington, D.C.: CQ Press.

Fenno, R. F. 1962. The House Appropriations Committee as a political system: The problem of integration. American Political Science Review, 56(2): 310-324.

Fenno, R. F. 1966. The power of the purse: Appropriations politics in Congress. Boston: Little, Brown.

Fenno, R. F. 1973. Congressmen in committees. Boston: Little, Brown.

Ferejohn, J. A. 1974. Pork barrel politics: Rivers and harbors legislation, 1947-1968. Stanford, CA: Stanford University Press.

Fiorina, M. P. 1977. Congress, keystone of the Washington establishment. New Haven, CT: Yale University Press.

Fisher, L. 1975. Presidential spending power. Princeton, NJ: Princeton University Press.

Geiger, S. M. 1994. The House Appropriations Committee, FY 1963-82: A micro-budgetary perspective. Legislative Studies Quarterly, 19(3): 397-416.

Gist, J. R. 1978. Appropriations politics and expenditure control. Journal of Politics, 40(1): 163-178.

Glassman, M. E., \& Wilhelm, A. H. 2017. Congressional careers: Service tenure and patterns of member service, 1789-2017. Congressional Research Service. Retrieved on July 26, 2017, from https://fas.org/sgp/crs/misc/R41545.pdf. 
Kim, J. 2016. Average age at 55 and the percentage of first-term members reduced to 44\%. Hankookilbo. Retrieved on July 25, 2017, from www.hankookilbo.com.

Ippolito, D. S. 1981. Congressional spending: A Twentieth-Century Fund report. Ithaca, NY: Cornell University Press.

Kahn, J. 1997. Budgeting democracy: State building and citizenship in America, 18901928. Ithaca, NY: Cornell University Press.

Kiewiet, D. R., \& McCubbins, M. D. 1985. Congressional appropriations and the electoral connection. Journal of Politics, 47(1): 59-82.

Kiewiet, D. R., \& McCubbins, M. D. 1991. The logic of delegation: Congressional parties and the appropriations process. Chicago: University of Chicago Press.

Lee, R. D., Jr., Johnson, R. W., \& Joyce, P. G. 2013. Public budgeting systems (9th ed). Burlington, MA: Jones and Bartlett.

Lee, Y, \& Lee, N. 2017. Improving the parliamentary deliberation system on budget and accounts. Korea Journal of Public Finance, 10(2): 223-261.

Leloup, L. T. 1980. The fiscal Congress: Legislative control of the budget. Westport, CT: Greenwood Press.

Lende, H. 2005. Alaska's road to nowhere. New York Times, August 20. Retrieved on July 24, 2017, from www.nytimes.com/2005/08/20/opinion/alaskas-road-to-nowhere.html? $\mathrm{r}=0$.

Maass, A. 1983. Congress and the common good. New York: Basic Books.

Mayhew, D. R. 1974. Congress: The electoral connection. New Haven, CT: Yale University Press.

McCaffery, J. L. 1987. The development of public budgeting in the United States. In R. C. Chandler (ed.), A centennial history of the American administrative state (pp. 345-377). New York: Free Press.

McCubbins, M. D. 1990. Budget policy-making and the appearance of power. Journal of Law, Economics, and Organization, 6 (special issue): 133-153.

Ministry of Strategy and Finance. 2014. The budget system of Korea. Retrieved on July 24, 2017, at https://english.mosf.go.kr/images/TheBudgetSystemofKorea. pdf.

Office of Management and Budget. 2016. Historical tables. Retrieved on July 27, 2017, from www.whitehouse.gov/sites/whitehouse.gov/files/omb/budget/ fy2018/hist.pdf.

Oleszek, W. J. 2011. Congressional procedures and the policy process (3rd ed). Washington, DC: CQ Press.

Rohde, D. W. 1991. Parties and leaders in the postreform House. Chicago: Chicago University Press.

Savage, J. D. 1991. Saints and cardinals in appropriations committees and the fight 
against distributive politics. Legislative Studies Quarterly, 16(3): 329-347.

Shepsle, K. A. 1978. The giant jigsaw puzzle: Democratic committee assignments in the modern House. Chicago: University of Chicago Press.

Shepsle, K. A., \& Weingast, B. R. 1981. Political preferences for the pork barrel: A generalization. American Journal of Political Science, 25(1): 96-111.

Shepsle, K. A., \& Weingast, B. R. 1984. Legislative politics and budget outcomes. In G. B. Mills \& J. L. Palmer (eds.), Federal budget policy in the 1980s (pp. 343367). Washington, DC: Urban Institute Press.

Schick, A. 1980. Congress and money: Budgeting, spending, and taxing. Washington, DC: Urban Institute Press.

Schick, A. 1981. The three-ring budget process: The appropriations, tax, and budget committees in Congress. In T. E. Mann \& N. J. Ornstein (eds.), The new Congress (pp. 288-328). Washington DC: American Enterprise Institute for Public Policy Research.

Schick, A. 2007. The federal budget: Politics, policy, process (3rd ed). Washington, DC: Brookings Institution Press.

Skocpol, T. 1995. Social policy in the United States: Future possibilities in historical perspective. Princeton, NJ: Princeton University Press.

Skowronek, S. 1982. Building a new American state: The expansion of national administrative capacities, 1877-1920. New York: Cambridge University Press.

Stewart, C., III. 1987. Does structure matter? The effects of structural change on spending decisions in the House, 1871-1922. American Journal of Political Science, 31(3): 584-605.

Stewart, C., III. 1988. Budget reform as strategic legislative action: An exploration. Journal of Politics, 50(2): 292-321.

Stewart, C., III. 1989. Budget reform politics: The design of the appropriations process in the House of Representatives, 1865-1921. New York: Cambridge University Press.

Weingast, B. R., Shepsle, K. A., \& Johnson, C. 1981. The political economy of benefits and costs: A neoclassical approach to distributive politics. Journal of Political Economy, 89(4): 642-664

Wildavsky, A., \& Caiden, N. 2004. The new politics of the budgetary process (5th ed). New York: Pearson/Longman.

Wilmerding, L., Jr. 1943. The spending power: A history of the efforts of Congress to control expenditures. New Haven, CT: Yale University Press.

Wood, G. S. 1969. The creation of the American republic. Chapel Hill: University of North Carolina Press. 
